\title{
'Impossible' re-introduction of the endangered limpet Patella ferruginea Gmelin, 1791? Progress in resolving translocation mortality
}

\author{
D. A. Fa ${ }^{1,2, *}$, G. Finlayson ${ }^{1,2}$, J. Sempere-Valverde ${ }^{3}$, J. C. García-Gómez ${ }^{3,4}$ \\ ${ }^{1}$ The University of Gibraltar, Europa Point Campus, Gibraltar GX11 1AA \\ ${ }^{2}$ The Gibraltar National Museum, 18-20 Bomb House Lane, Gibraltar GX11 1AA \\ ${ }^{3}$ Laboratorio de Biología Marina, Dpto. Zoología, Universidad de Sevilla, Av. Reina Mercedes 6, 41012 Sevilla, Spain \\ ${ }^{4}$ Área de Investigación Biológica I+D+I del Acuario de Sevilla, Muelle de las Delicias s/n, 41012 Seville, Spain
}

\begin{abstract}
The Mediterranean ribbed limpet Patella ferruginea Gmelin, 1791 is the most endangered marine invertebrate listed in the EU Habitats Directive. A diversity of anthropic pressures have reduced its present-day distribution to a fraction of its former size. Perhaps surprisingly, this highly protected species has successfully established along man-made harbour breakwaters, resulting in serious complications when these structures have required modification or repair, often leading to costly impasses due to the legal status of the species. Attempts to move the limpets to other locations have resulted in unacceptably high mortality rates. This article describes the result of a field experiment where $97 \mathrm{P}$. ferruginea individuals were transported to a new site, using a technique which involved carefully moving the limpets whilst inactive (during low tide), still attached to their home scars on breakwater boulders. The results of this experiment were significantly positive, with $87 \%$ of all translocated limpets still alive 10 mo after the move, a mortality rate which compared favourably with that obtained for the existing control population at the receptor site. We propose that this method could be a practical solution to address the conflicts generated by this endangered species' preference for harbour constructs. We further propose that this method can be used as a management tool to enhance the species' survival prospects, by creating 'stepping stones' of pockets of reproducing individuals that can connect currently fragmented populations to effect a population recovery of this threatened organism.
\end{abstract}

KEY WORDS: Patella ferruginea $\cdot$ EU Habitats Directive $\cdot$ Endangered species $\cdot$ Conservation management · Rocky intertidal · Artificial coastal constructs · Artificial marine micro-reserves · AMMRs $\cdot$ Gibraltar

\section{INTRODUCTION}

\section{Conservation status, ecology and traits}

Limpets are considered key species in coastal ecosystems, as they create and maintain bare rock patches in the rocky intertidal and limit the coverage of barnacles and macroalgae, enabling many species to coexist and contributing to marine biodiversity on rocky shores (Branch 1981, Espinosa \& Rivera-Ingraham 2017). The limpet Patella ferruginea Gmelin,

\footnotetext{
${ }^{*}$ Corresponding author: darren.fa@unigib.edu.gi
}

1791 (Gastropoda, Patellidae) is the most endangered marine invertebrate along the western Mediterranean rocky shoreline (Laborel-Deguen \& Laborel 1991a, Ramos 1998, Espinosa et al. 2005, Rivera-Ingraham 2010, Rivera-Ingraham et al. 2015), and as such is listed in Annex IV of the European Union's Habitats Directive (92/43/EEC; EC 2004). It is endemic to the western Mediterranean, but presently its distribution is restricted to only a few sites along this basin (Cretella et al. 1994, Arroyo et al. 2011, Casu et al. 2011, Fernández et al. 2017). Despite archaeological evi-

() The authors 2018. Open Access under Creative Commons by Attribution Licence. Use, distribution and reproduction are unrestricted. Authors and original publication must be credited. 
dence showing a more widespread distribution in the past, including its presence in Palaeolithic and Neolithic deposits throughout the western Mediterranean (where it was presumably collected as food; Fa 2008), it has regressed significantly in recent history - likely due to increasing levels of various anthropogenic pressures (Aversano 1986, Laborel-Deguen \& Laborel 1991a,b), including collection (for possible consumption, use as bait, or decoration), habitat deterioration and pollution.

As with other species of giant limpets (>10 cm maximum shell diameter), $P$. ferruginea individuals may have a lifespan of over $30 \mathrm{yr}$ and are very slow growing, reaching sexual maturation at 2 to 3 yr (Espinosa 2005, Espinosa \& Rivera-Ingraham 2017). As with many invertebrate species, intra- and inter-specific variation in limpet size is correlated with gradients of primary productivity and nutrient availability, which are expected to determine individual size and population densities and dynamics (Bosman et al. 1987, Fa 2008, Espinosa \& Rivera-Ingraham 2017). Fa (2008) also pointed to restricted tides in the Mediterranean (reduced width of the mid-littoral zone) as an important factor in determining population density (ind. $\mathrm{km}^{-1}$ of coastline) of such relatively large littoral species, reducing maximum sustainable yields which would be further depressed by size-based collection (negatively affecting existing sex ratios). Consequently, the larger maximum sizes and population densities of $P$. ferruginea near the Straits of Gibraltar may have contributed to increased larvae production and recruitment and thus increased resilience to anthropic pressures compared with the rest of the Mediterranean Sea (Bosman et al. 1987, Le Quesne 2005, Espinosa et al. 2006, Fa 2008, Espinosa \& Rivera-Ingraham 2017).

$P$. ferruginea is usually considered a protandric species, being initially male (from around $25 \mathrm{~mm}$ length) and latterly female (from around $60 \mathrm{~mm}$ length; Espinosa 2005, Espinosa et al. 2006); but it can also exhibit a reverse sex change, whereby females can turn again to males (Guallart et al. 2013). However, this situation is by no means clear-cut, with differences having been observed between populations located along open-sea environments and those found on port structures. For example, González et al. (2015) found that in Melilla, on the North African Mediterranean coast, initial maturation into males took place at around $3 \mathrm{~cm}$ at open-water sites but increased to $4 \mathrm{~cm}$ within ports, with a clear dominance of males up to $5 \mathrm{~cm}$ size in the former and $6.5 \mathrm{~cm}$ in the latter. They reported finding males up to $8 \mathrm{~cm}$ in size within port environments, whereas females were found as small as $4 \mathrm{~cm}$ in open-water sites. These differences may alter natural reproductive rates, considering that $P$. ferruginea is, in European waters, the only endangered marine species that has successfully established along man-made rocky coastal infrastructures such as jetties and breakwaters (RiveraIngraham et al. 2011a,b, Espinosa et al. 2014). This has led to the proposal by García-Gómez et al. (2011, 2015) that certain harbour structures could be used as 'artificial marine micro-reserves' (AMMRs) for this species (see also Firth et al. 2016, Shabtay et al. 2018). It has to be noted that the exact census of small individuals and recruits in rip-rap structures may be very difficult because of the cryptic and hardly accessible micro-habitats that occur inside porous coastal defence structures (authors' pers. obs.). These structures support higher species diversity than more exposed external surfaces, which are more prone to damage, disturbances by anthropic pressures, wave exposition and predation (Sherrard et al. 2016).

Homing behaviour or scar fidelity has been observed in several species of Patelloidea, although in general it does not occur in small individuals (Branch 1981). It has been described in $P$. ferruginea by Espinosa et al. (2007, 2008a), Rivera-Ingraham (2010) and also by Peña et al. (2012) for specimens kept in captivity. On the other hand, changes of home scar were described for $P$. ferruginea by Laborel-Deguen \& Laborel (1990, 1991b), with the observations that these occurred more frequently in winter, less so in spring and autumn and never in summer (Guallart 2006, Guallart \& Acevedo 2006).

The relatively large sizes of the ovocites of $P$. ferruginea suggest a short planktonic phase (Frenkiel 1975), lasting approximately 3 d according to González et al. (2015). P. ferruginea is therefore considered a K-strategist (Laborel-Deguen \& Laborel 1991b). This short planktonic phase suggests that gene flow may be present only at small geographic scales (Casu et al. 2006). The relatively high genetic diversity within populations in 2 natural marine protected areas (MPAs) in the north of Sardinia provides supporting evidence (Cossu et al. 2017). On the other hand, Casu et al. (2011) identified 2 main genetic groups within the Mediterranean and hypothesised that gene flow may occur between populations from the Straits of Gibraltar to Sicily. In addition, Fauvelot et al. (2009) reported lower genetic diversity in populations of $P$. caerulea on artificial substrata when compared with natural ones - a situation that may also be occurring in other patellid species, and which raises concerns regarding the future approach to $P$. ferruginea investigation and conservation efforts. 


\section{Harbours and re-introduction in natural habitats: an unsolved conservation problem}

The translocation of specimens is a useful tool for many short-ranged endemic species facing local and regional threats (Griffith et al. 1989, Hoegh-Guldberg et al. 2008, Swan et al. 2016). Yet the use of this tool to favour species dispersal through assisted colonization is controversial. Some authors argue that, in the current context of climate change, translocations of short-range endemics should be carried out considering their projected future 'native' range rather than within their historical range (Müller \& Eriksson 2013). In any case, translocation has the potential to reduce net decline in global species diversity (Müller \& Eriksson 2013), and thus creation and validation of translocation methodologies is important given the current decline of many invertebrate species in the Mediterranean, which is considered to be a direct or indirect a direct or indirect consequence (such as proliferation of diseases) of water warming (Bianchi \& Morri 2000, Maldonado et al. 2010, Cebrian et al. 2011, Pairaud et al. 2014, Rivetti et al. 2014, Di Camillo \& Cerrano 2015, Rivetti et al. 2017).

According to Bullock et al. (1996), the ecological impact of translocated species over hosting habitat communities may be either deleterious or beneficial and, before any translocation of native species, certain assessment criteria need to be established in order to know the potential impacts of translocations and the factors which might influence survival rates. Following the Guidelines for Reintroductions and Other Conservation Translocations, IUCN/SSC (2013, p. 5), the use of conservation translocations for the reinforcement and reintroduction within a species' indigenous range must 'be justified', 'have clearly defined goals' (intended results) and 'follow a logical process from initial concept to design, feasibility and risk assessment, decision-making, implementation, monitoring, adjustment and evaluation'.

Attempts at the direct transfer of individual specimens of limpets have poor records of success, as they led to significant mortalities when individuals were mechanically removed and displaced to new locations. In this regard, Laborel-Deguen \& Laborel (1991a) and Espinosa et al. (2008b) reported a mortality of almost $50 \%$ within the first $12 \mathrm{~h}$ following translocation of $P$. ferruginea specimens (increasing to $75 \%$ mortality after $1 \mathrm{yr}$ and $88 \%$ after $2 \mathrm{yr}$ in the former study). Seemingly, Guallart (2014) highlighted the attempts at translocation of $P$. ferruginea that have occurred in Spain, and the associated low survival rates. Nonetheless, Zarrouk et al. (2018) recently reported survival rates of $60 \%$ after 2 yr in Zembra, Tunisia, by using cages to protect against predation and wave action. Subsequent attempts to move the specimens whilst still attached to their rocks also met with little success (F. Espinosa pers. comm.); translocations had only been attempted with rocks which were small enough to be lifted by hand, and which were transported in an unsupported fashion in a car to a new site. In a number of cases, the limpets released themselves from the rocks and reattachment was unsuccessful. It was surmised that vibrations caused by the transport process may have caused this. Other limpets survived the transport and resettlement process, only to disappear soon after. The researchers who carried out this experiment suggested that the relatively small size of the translocated rocks and the nature of the area where they were placed may have created too high a degree of instability for the limpets (F. Espinosa pers. comm.). Because of these poor survival data, the Spanish National Conservation Strategy for that species (MMAMRM 2008) categorically rejected the translocation of specimens as a viable conservation tool.

The ability of $P$. ferruginea to colonize man-made coastal structures has led to an additional unsolved problem in many ports and other artificial coastal constructs within the western Mediterranean, as the same breakwaters that shelter the populations of this endangered species frequently require restoration, modification or reconstruction (Guerra-García et al. 2004a). An example of this situation is the recent stoppage of major port infrastructure works in the harbour of Ceuta (Spanish enclave in North Africa) due to the presence of this species, with concomitant costs estimated to be in the millions of Euros (for example, the negative Environmental Impact Statements for the expansion projects of the Port of Ceuta, Phase III, and the Port of Tarifa, in 2009 and 2011, respectively). In some cases, the conflict that may arise between legitimately competing demands for the same stretch of shoreline is such that $P$. ferruginea individuals may face being sacrificed under the derogatory process provided for this purpose by the EU in its Habitats Directive (Article 16). It is surmised that any new methodologies which could save such individuals and guarantee their long-term survival would be welcomed. Such methodologies would also be applicable to develop conservation strategies for other limpet species and the emerging field of limpet aquaculture (Angel et al. 2006, Mau \& Jha 2017).

The main aim of the present paper was to propose a new translocation method which avoids the problems associated with transferring individuals by 
mechanical extraction and subsequent relocation to different substrates, which, as already noted, causes significant mortality. This mortality is especially high in larger specimens with reduced capacity for fast growth, as they are limited in their ability to form a watertight seal with the new substrate following translocation, and therefore are exposed to dehydration and asphyxia during low tide.

\section{MATERIALS AND METHODS}

\section{Location and background}

The severe storm which struck Gibraltar on 5 November 2008 significantly damaged a number of rock revetments which the species was known to inhabit. Several of the damaged areas were part of a reclamation which had been carried out by HM Government of Gibraltar in the late 1980s, and which had been subsequently colonised by Patella ferruginea, probably over the previous $15 \mathrm{yr}$. Subsequent wave studies indicated that changes to the wave patterns within the Bay, possibly caused by recent works to the port of Algeciras across the Bay of Gibraltar, may have been the causal agent. This affected the existing wave pattern predictions for the Gibraltar coast, and the likelihood of repeat storms of similar magnitude became much higher. Subsequently, a re-assessment of the construction of the rocky revetments and sea defences within the harbour was conducted, with the outcome being a decision to rebuild these structures, both stronger and higher. Although a number of specimens had been lost to the storm, there were still sufficient $P$. ferruginea along and close to areas that, for health and safety reasons, required urgent repair and remodelling. The scale of the proposed works was therefore in direct conflict with the EU's requirement that such species should not be placed under risk.

As part of the requisite pre-disturbance assessment of existing populations of $P$. ferruginea, we censused a total of 97 individuals along a stretch of coastline earmarked for urgent repairs, known as the MidHarbour revetment (area A in Fig. 1) (Fa \& Finlayson 2008). Rather than seek derogation under the EU'S Habitat's Directive, the decision was taken, in consultation and with the support of representatives of HM Government of Gibraltar, to attempt to translocate the threatened individuals to a receptor site that was known to contain individuals of the same species and was not presently under risk. A significant section of the North Mole (area B in Fig. 1) was found to still contain 143 individuals of $P$. ferruginea. This site

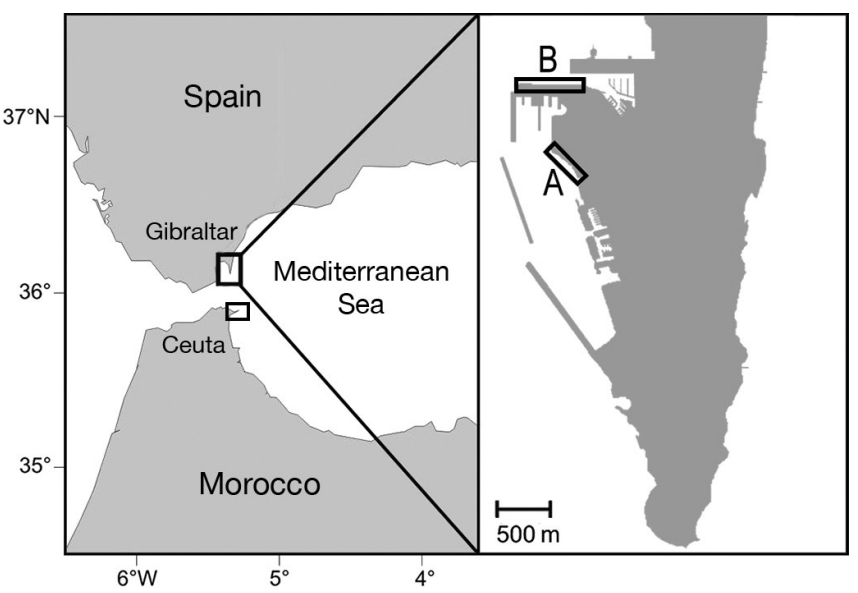

Fig. 1. Location of Gibraltar, with detailed map showing Patella ferruginea translocation sites: (A) Mid-Harbours (donor site); (B) North Mole (receptor site)

had exhibited an increase in numbers of individuals over the recent past and, as this area was not under consideration for repairs, the decision was taken to translocate the Mid-Harbour individuals to this site.

\section{Translocation methodology}

Translocations were carried out by moving large boulders with limpets still attached (as opposed to simply moving the specimens), a procedure that meets IUCN/SSC (2013) recommendations. This technique has the advantage of moving a limpet together with its home scar and a fraction of its grazing area, reducing the physical stresses associated with the actual translocation (and possible minor changes in such factors as orientation and exposure). This also addresses the recently demonstrated 'memory' which this organism has of the surrounding topography, acquired during its foraging excursions (Espinosa et al. 2008a), and therefore moving both animal and associated substrate would also reduce stress. The main difficulties faced were logistic: some boulders weighed from several hundred kg to over 2 tons (t), and their transport and subsequent placement required adequate prior planning, site preparation and careful positioning of the rocks in their new locations (Fig. 2). At the same time, it was necessary to ensure that the attached $P$. ferruginea individuals remained unharmed.

A total of $97 P$. ferruginea individuals were located along and close to the area due for repair. These were measured to the nearest $0.1 \mathrm{~mm}$ using callipers, and data on their orientation, location on the rock, 
Fig. 2. Various stages in the Patella ferruginea translocation process: (A) crane barge used for lifting rocks in areas inaccessible to a JCB crane; (B) JCB crane used for moving the majority of boulders; (C) Vernier callipers illustrating how individuals were measured; (D) Garmin GPS used to aid location; (E) breakwater boulder with $P$. ferruginea individual (indicated by white dashed oval); arrow points to one of several locator arrows painted on surrounding rocks; (F) using the crane's mechanical arm to create space around the rock to be moved. The base of the yellow arrow indicates the same painted arrow in $(\mathrm{E})$; (G) raising the boulder after having secured it with slings; $(\mathrm{H})$ placing the boulder on top of car tyres and lashing it down to minimise in-transport vibrations. $P$. ferruginea individual is indicated by the dashed white oval. Note that the slings are positioned well clear of the limpet, and are left in place to facilitate re-inserting at the donor site; (I) low-loader lorry ready to transport the rocks to the donor site

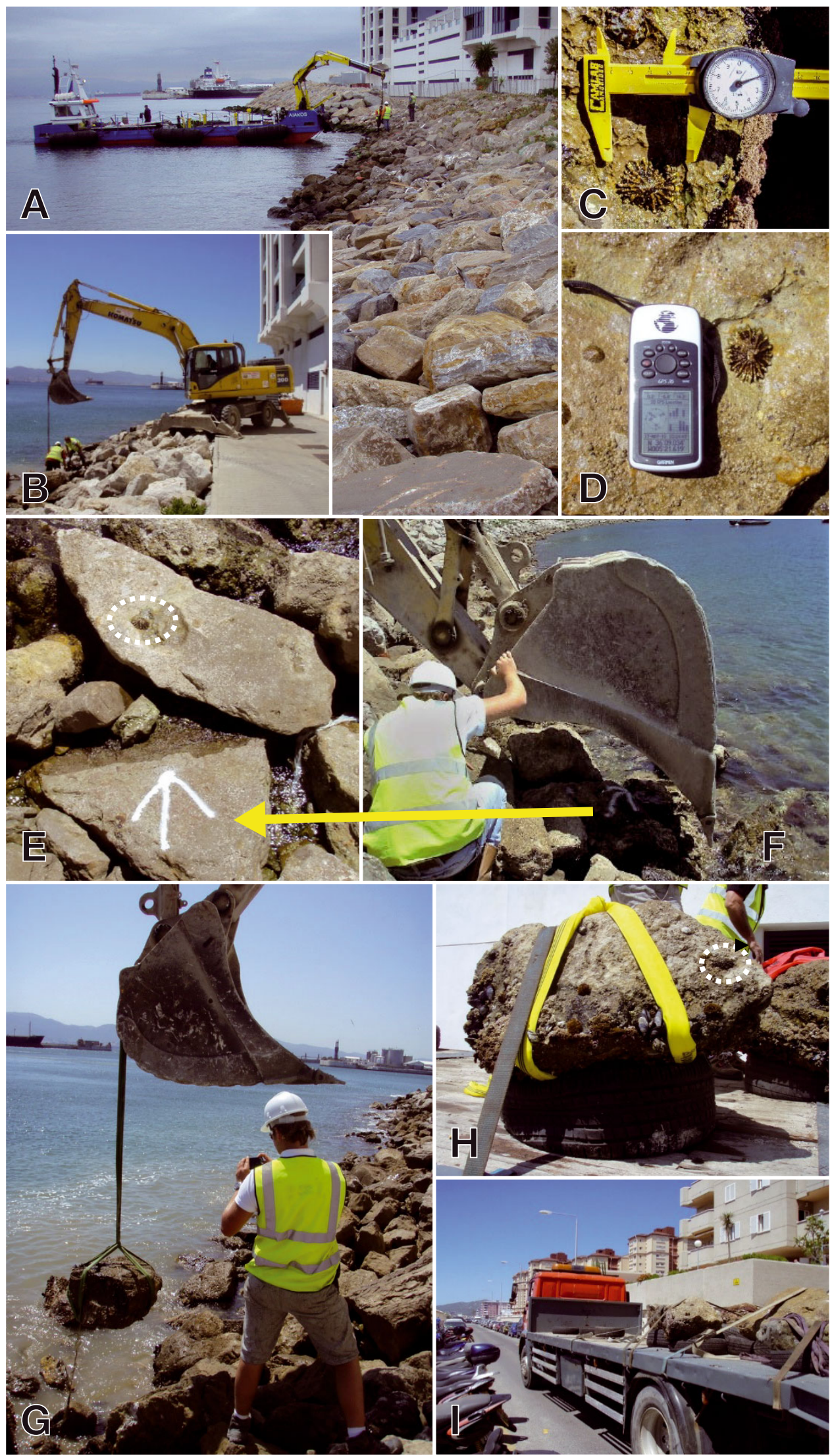


height above sea level relative to tidal height and position were collected (Fig. 2C). Positional data were taken using a GARMIN 76S GPS (Fig. 2D). Each rock was individually marked, as far away from the limpet as was practical, using a small blob of Eporai ${ }^{\circledR}$ resin and a unique identifier number embossed into the resin. The resin, which hardens by a chemical reaction, set hard well within the time taken to transfer the individuals. This was done to avoid stressing and also drawing attention to the animal, which may encourage harvesting, both identified as negative consequences of directly marking the shell.

A separate census of the individuals along the chosen receptor section of the North Mole was also undertaken, and the same data collected for a total of 143 resident $P$. ferruginea individuals found there. These data therefore allowed the comparative monitoring of both translocated and resident populations, allowing the latter to act as a natural control. This survey identified sectors of the North Mole coastline where there were no resident limpets that could be disturbed by the translocation process. The translocated limpets would therefore be inserted into an intertidal ecosystem that was already matured and diverse, and which already contained a number of individuals of the same species nearby, indicating that it would be a suitable receptor site.

Data for this location had already been collected (Fa 2005, Fa \& Finlayson 2008) and, together with the data censused in 2010, provided an assessment of the changes in population structure over time at this site. The abundances were used to obtain lambda $(\lambda$, finite rate of increase) between censuses. Individuals were size-classified according to the later sexual maturation detected in populations over artificial structures to obtain an estimation of the number of males (5 to $6.99 \mathrm{~cm}$ ) and females ( $\geq 7 \mathrm{~cm}$; see 'Introduction'; González et al. 2015).

As described above, a survey was carried out of the entire donor site to establish the exact location and situation of any $P$. ferruginea individuals. During this survey, arrows indicating the relevant boulders were painted on nearby rocks using white spray paint (Fig. 2E). This was done to provide clear visual cues to the crane and sling operators regarding which rocks needed to be moved as well as highlight any important information, such as when the rocks might be overlaid by others, requiring a greater degree of manipulation to avoid generating instability in the breakwater following extraction. Most of the rocks to be moved were of relatively uniform size and weighed on average around $1 \mathrm{t}$, but some ranged from very large $(\sim 2.5 \mathrm{t})$ to very small $(\sim 0.05$ to $0.2 \mathrm{t}$ ).
To minimise disturbance to the animals themselves, the operation took place during low tide cycles, when the limpets were settled at their home scars. The rocks were secured individually using under-slung lifting straps (taking special care not to affect the limpets in any way) and carefully raised using a JCB crane, or where necessary, a crane barge (Figs. 2A,B,G). The straps minimised both the amount of direct contact and the level of machine-induced vibration transferred to the rocks during the procedure. A lowloader truck was used to transfer the rocks (Fig. 2I). The rocks were placed directly onto car tyres to cushion against the vehicle's vibrations during transfer, and securely lashed to the truck's platform with a second set of straps (the original straps were left in place beneath the rock to minimise handling and facilitate re-lifting from the truck when it reached its destination; Fig. 2H).

Around 5 limpet-bearing rocks were transferred per instance. The truck was driven very slowly, to minimise disturbance to the organisms. Still within the same low tide cycle, the rocks were carefully placed into previously selected sections of the receptor site where no $P$. ferruginea individuals were located, following essentially a reverse procedure to that followed for extraction. In some cases, some movement of surrounding rocks was required in order to create a suitable insertion point, but this was kept to a minimum to lessen possible disturbance to nearby limpets (i.e. silting of the water etc.). In general, the large size of the boulders meant that, once placed, there would be little or no movement of the rocks with wave action or other direct physical disturbances. However, some limpets were on small rocks and these were wedged in using other rocks from the same stretch of shore to make them as secure as possible. Two limpets had home scars on concrete structures, and this necessitated breaking up the concrete using hydraulic machinery. Unfortunately, the resulting fragments (with attached limpets) were very small, but the 2 limpets were also transferred to the recipient site along with the others.

Placement of the rocks was carried out by hand whilst the crane took the load. This allowed the researchers to make small adjustments to orientation and height above sea level (taking into account the change in tide with elapsed time) to best approximate the original conditions at the donor site. In some cases, it was not possible to match all of these factors - particularly orientation, given that the donor site faced south-west and the receptor site faced north. In these cases, the limpets were placed facing out to sea, but height above sea level (taking into account 
time elapsed since collection) and general disposition of the rock were approximated as closely as possible.

Given the time limitations placed by the tidal cycle (spring vs. neap tides) and other factors such as available light, inclement weather, equipment and personnel availability and the fact that the entire repair project was phased over several months, meant that the entire translocation of all 97 P. ferruginea individuals to the receptor site on the North Mole took place between June and November 2010. Fig. 3 shows the frequency of $P$. ferruginea individuals (both resident and translocated) along the receptor site upon completion of the exercise.

\section{Monitoring methodology}

The stretch of coastline along the North Mole was divided into a series of $50 \mathrm{~m}$ sections. An eyelet was drilled into the rock at the start and finish of each $50 \mathrm{~m}$ section approximately $3 \mathrm{~m}$ from the high-water mark. These were subsequently used as anchor points for a $50 \mathrm{~m}$ long tape measure (the datum line). The position of each limpet away from this tape was established by using the $50 \mathrm{~m}$ tape as the $x$-axis and measuring off the perpendicular distance ( $y$-axis) of each limpet, with points above the datum marked as positive and those below as negative. This datum offset technique is a common method for initial baseline surveys and proved a more effective way of locating limpets than using a GPS device, which can have significant error at small scales. It moreover provides accurate spatial distribution data which are amenable to subsequent analyses such as nearest-neighbour, etc.

Individual mortalities for both resident and translocated populations were registered from October 2010 to March 2011, 4 mo after final translocations. Throughout the monitoring period, limpet location data were collected as described above (a number of individuals were observed to naturally move their home scar during the survey period), and size of the shell long axis (measured using callipers to the nearest $0.1 \mathrm{~mm}$ ) was also measured. To establish if there were any additional factors that could have a bearing on survivorship, other parameters were measured, including height above sea level, orientation and disposition on the rock (beneath an overhang, perpendicular, inclined, above or in a rock pool).

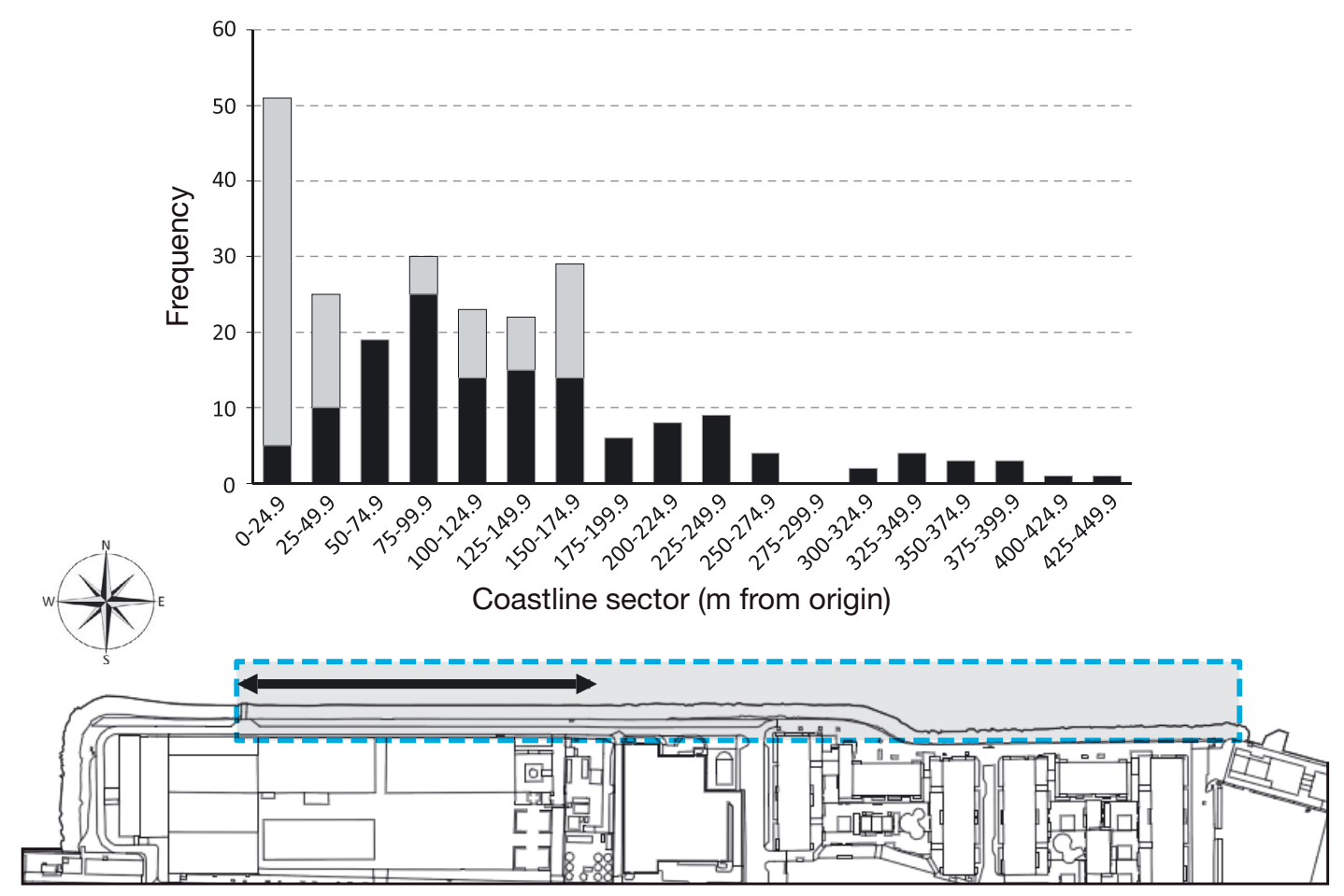

Fig. 3. (Bottom) North Mole receptor site (area B in Fig. 1). The grey rectangle within the dashed blue line represents the survey area, and the black arrow the area over which translocated individual Patella ferruginea were inserted. (Top) The histogram above shows the total frequency of $P$. ferruginea individuals along the site, approximately scaled to size. Black bars: existing numbers of resident and their distribution across the site; grey bars: numbers of transposed individuals. The low numbers of resident limpets towards the extreme west were due to damage caused by a storm in November 2008 (see 'Materials and methods: Location and background') 


\section{Statistical analyses}

Kolmogorov-Smirnov and Levene analyses were carried out with limpet size data sets for both resident and translocated populations to test normality and equality of variances. When homoscedasticity was confirmed, a 1-way ANOVA was calculated to contrast both population means.

Limpet home-scar inclinations were summarised into an ordinal variable with 1 (vertical), 2 (slightly inclined) and 3 (horizontal) values. KolmogorovSmirnov and Mann-Whitney tests were carried out to test normality within and differences between resident and translocated populations. Also, KolmogorovSmirnov and Levene analyses were applied to test limpet height above sea level normality and homocedasticity in the receptor section of the North Mole. A Kruskal-Wallis test was carried out to test differences between resident and translocated populations.

Mortality and permanence/displacement of the home-scar were treated as 2 categorical dichotomous variables and differences between populations were tested using Fisher's exact test. All analyses were carried out using SPSS Statistics v.22 (IBM).

\section{RESULTS AND DISCUSSION}

\section{Resident and translocated populations}

The size class distributions of the North Mole (resident) population over time (Fig. 4) indicated evidence of several recruitment events which increased both the number of smaller-sized individuals and the total population size (37 ind. in 2005, 143 in this study). Lambdas between censuses reflected the increase of individuals (2005 to $2008 \lambda=1.95 ; 2008$ to $2010 \lambda=$ 1.93). Also, from 2005 to 2010 the size-class 5.00 to $6.99 \mathrm{~cm}$ shell diameter (presumably males) increased from 25 to 55 individuals. This was not the case with individuals larger than $7 \mathrm{~cm}$, which declined from 6 to 4 during these surveys. In any case, the increasing densities of size-classes between 4 and $6 \mathrm{~cm}$ may indicate a rise in the number of females, as in some patellogastropods (including Patella ferruginea) the change from male to female appears to occur at smaller sizes in populations where large individuals are rare (Wright 1989, Rivera-Ingraham et al. 2011b, Borges et al. 2016). The low number of females was likely caused by recognised anthropic pressures, which tend to selectively focus on larger individuals (Aversano 1986, Laborel-Deguen \& Laborel 1991a,b, Espinosa \& Rivera-Ingraham 2017).

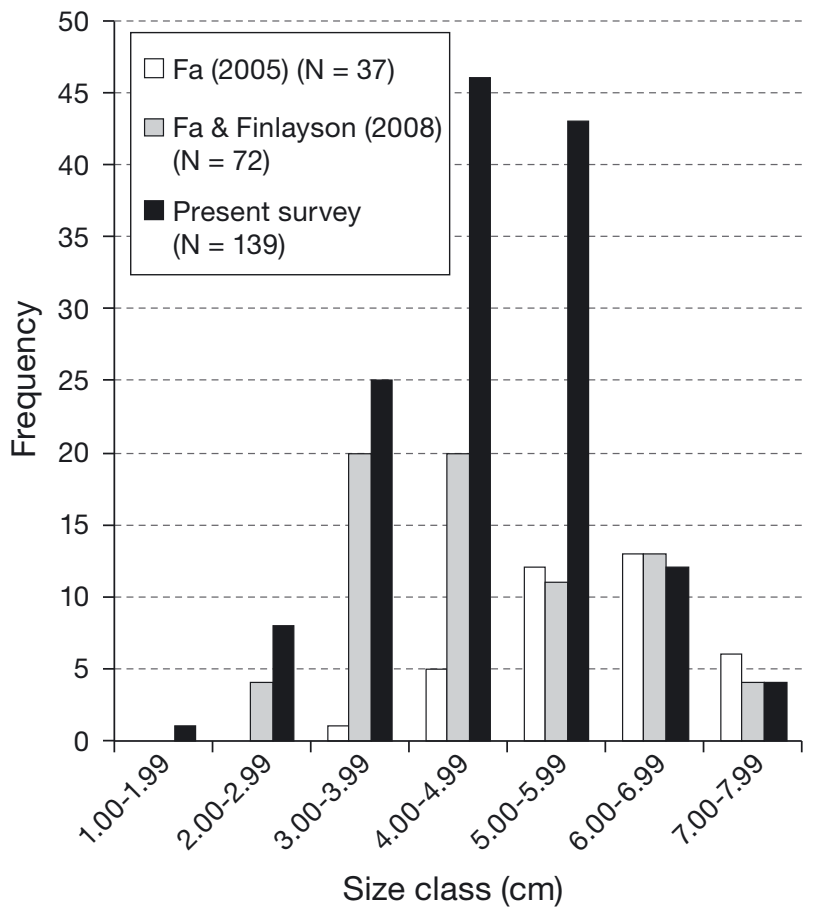

Fig. 4. Size class distributions of Patella ferruginea illustrating the evolution of the North Mole population over time. It was not possible to obtain size data for 4 ind. in the present survey

Fig. 5 shows the size-class distributions for both resident and translocated populations of $P$. ferruginea. Univariate analyses were performed to confirm the existence of significant differences between these data sets. Both resident and translocated populations were found to be normally distributed (KolmogorovSmirnov $=0.026, \mathrm{p}=0.2$; Shapiro-Wilk $=0.997, \mathrm{p}=$ $0.887)$. Levene's test indicated homogeneity of variances $(p=0.576)$ and 1-way ANOVA established significant differences between the means of both populations $(F=8.66, \mathrm{p}=0.004)$.

Resident and translocated populations' inclinations (vertical, slightly inclined and horizontal) were found to be normally distributed (Kolmogorov-Smirnov $=$ $0.765, p=0.6$ ) and a Mann-Whitney test highlighted no differences between resident and translocated limpet inclinations $(p=0.096)$. Data obtained for the resident population (Figs. 6 \& 7) clearly established this species' preference for inclined surfaces and an orientation facing out to sea. However, these results must be interpreted carefully, as sampled surface area was not standardized between orientations (boulders' exposed surface is expected to be higher for orientations facing the sea, while inward orientations are more frequently covered by other boulders of the rip-rap structure). A similar situation occurs with inclinations (the irregular shape of boulders 


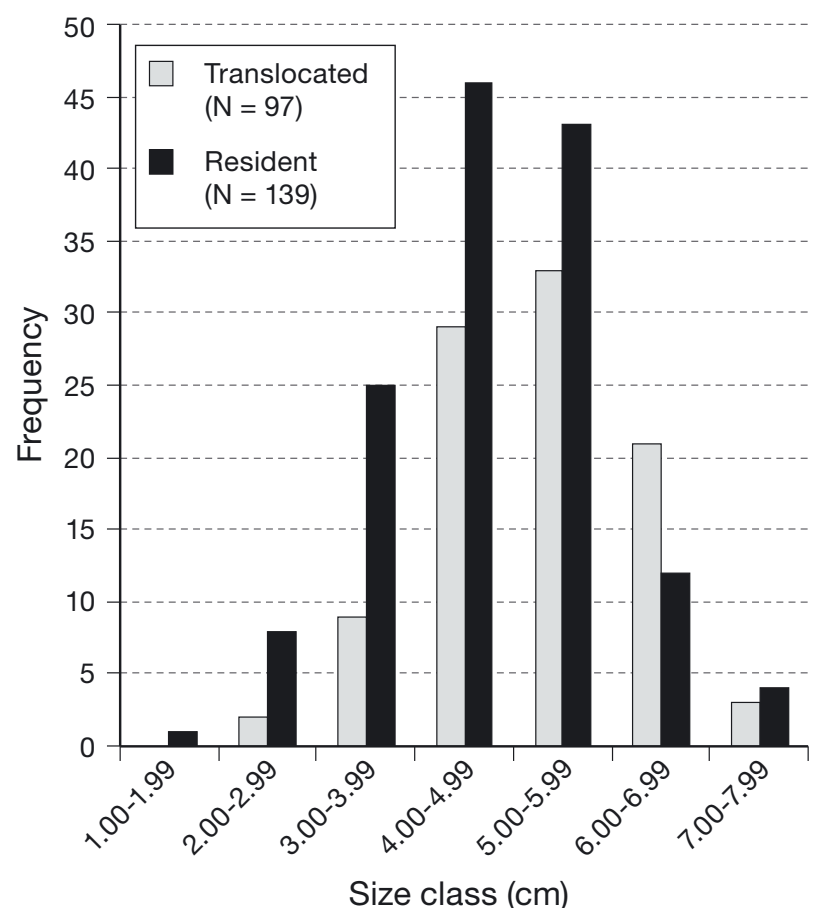

Fig. 5. Size class distributions of the translocated (mean $\pm \mathrm{SD}$ $51.94 \pm 10.79$ ) and resident (mean \pm SD $47.69 \pm 11.03$ ) populations of Patella ferruginea. It was not possible to obtain size data for 4 resident individuals

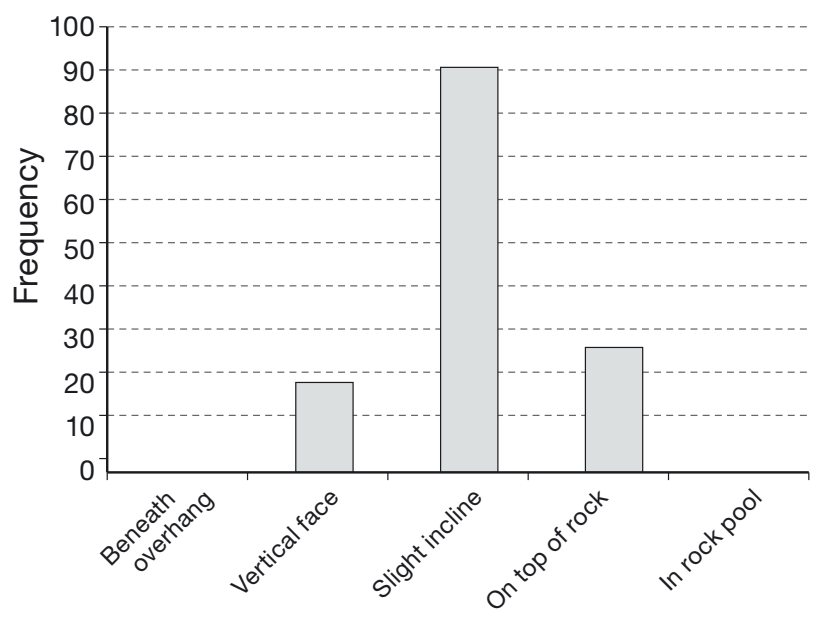

Fig. 6. Frequency of the resident Patella ferruginea individuals surveyed along the North Mole with regard to positional distribution

may alter within sampled areas and unequally affect the probabilities of finding individuals between treatments). Nonetheless, the high number of limpets found on surfaces facing south also suggests a preference for increased exposure to light. This has important implications regarding the design of harbour structures that incorporate a conservation design component.

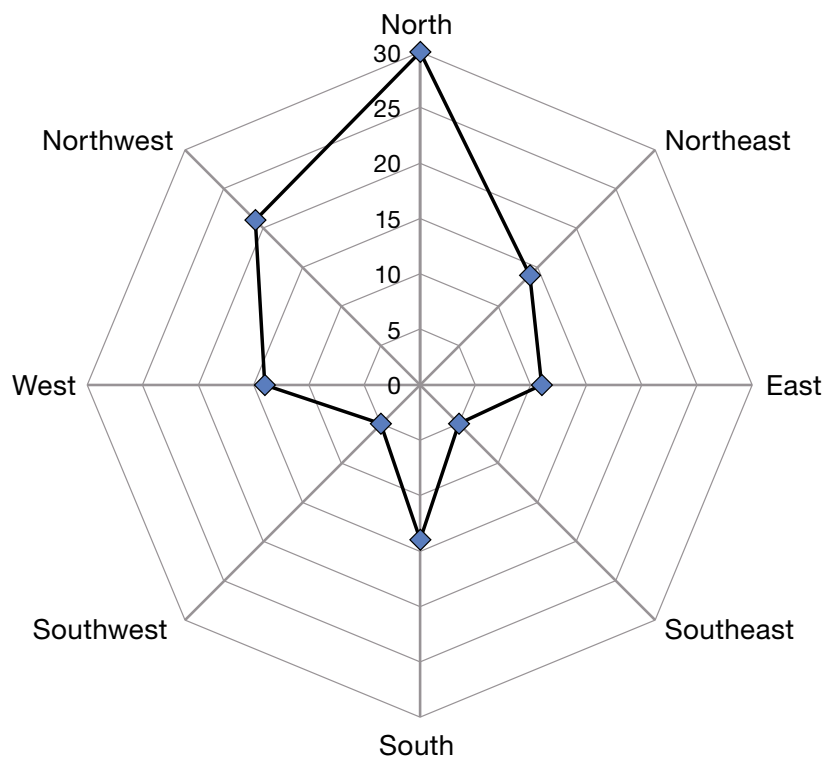

Fig. 7. Frequency of distribution of the various orientations of the resident Patella ferruginea individuals surveyed along the North Mole

\section{Population responses and survival of translocated individuals}

The limpets were monitored at monthly intervals over 10 mo following translocation (June 2010 to April 2011), and the results are presented in Table 1. After the first month, 2 of the smaller translocated rocks were not found. They may have been loosened and dislodged into the sea, or the marker may have come unstuck. The latter is almost certainly the case for 1 individual whose sudden appearance corresponded with the absence of a marked rock, but given that we were not able to unequivocally identify it as having been one of the translocated specimens, it was not included in the data set. In March 2011, after translocation, limpet height above sea level in

Table 1. Results after 282 days of monitoring translocated Patella ferruginea. Survival of the translocated individuals was higher than that of residents. Growth rates for both populations were similar

\begin{tabular}{|lcc|}
\hline & Translocated & Resident \\
\hline Number of individuals & 97 & 143 \\
Number not found & 13 & 30 \\
Mortality (\%) & 13.60 & 20.98 \\
Survival (\%) & 86.60 & 79.02 \\
Growth rate & $16.49 \pm 10.37$ & $17.41 \pm 10.35$ \\
$\quad\left(\mathrm{~mm} \mathrm{yr}^{-1}\right.$; mean $\left.\pm \mathrm{SD}\right)$ & & \\
\hline
\end{tabular}


the North Mole receptor site was higher for resident than translocated populations (Kolmogorov-Smirnov [translocated] $=0.115, \mathrm{p}<0.01$; [resident $]=0.126, \mathrm{p}<$ 0.01 ; Kruskal-Wallis $\mathrm{p}<0.01$ ). This may be a consequence of the boulders' readjustment to their final position by wave action rather than an incorrect positioning of boulders in the required tidal level into the receptor site, which would have created dispersion rather than mean differences between the heights of both populations (Levene $=2.754, \mathrm{p}=0.099$ ) .

Overall, these results are extremely encouraging. By the end of the monitoring period, 84 of the translocated 97 limpets were still in situ and surviving after 10 mo at the receptor site (86.6\% survivorship), potentially an underestimation given the loss of 2 specimens for which natural mortality cannot be assumed. This compares favourably with 113 remaining of the originally observed 143 limpets $(79 \%$ survivorship) for the resident population. Within the receptor section of the North Mole, no differences in mortality were found by Fisher's exact test ( $\mathrm{df}=1, \mathrm{p}<$ 0.091) between populations (Fig. 8).

Fig. 9 shows the mortalities obtained within each size class and indicates that although there were mortalities across all size classes for both populations, the highest percentage mortalities occurred toward the smaller and larger size classes (size classes 2 and 6 for translocated individuals, 3 and 6 for resident individuals). This is in all probability a statistical artefact caused by the disproportionate effect of loss of individuals within relatively accessible, yet proportionally numerically impoverished size classes. It may also have been affected by the increased probability of variation in environmental conditions that may have existed for resident individuals located further to the east along the Mole.

We discount the presence of newly inserted rocks as a possible contributor to the higher mortality of residents, as these rocks were only inserted into areas where no residents were found and therefore disruption, if any, would have been minimal.

Marginal differences in the abandonment of home scars following translocation were found using Fisher's exact test between resident and translocated populations ( $\mathrm{df}=1, \mathrm{p}=0.051)$. The change of home-scar and resettling at a new spot was relatively higher in the translocated population, but mortality was not. This may be due to the animals finding themselves in less-than-suitable locations after the move and opting to relocate to a better spot. Although this behaviour might have been precipitated by the translocation, retention of the original home scar would have allowed the organisms to explore the surrounding area to establish new positions as well as to build up the resources necessary for the rapid growth of new shell that is required when moving to a new location. The preliminary conclusion therefore is that the translocation method was successful in reducing stress to the organisms involved.

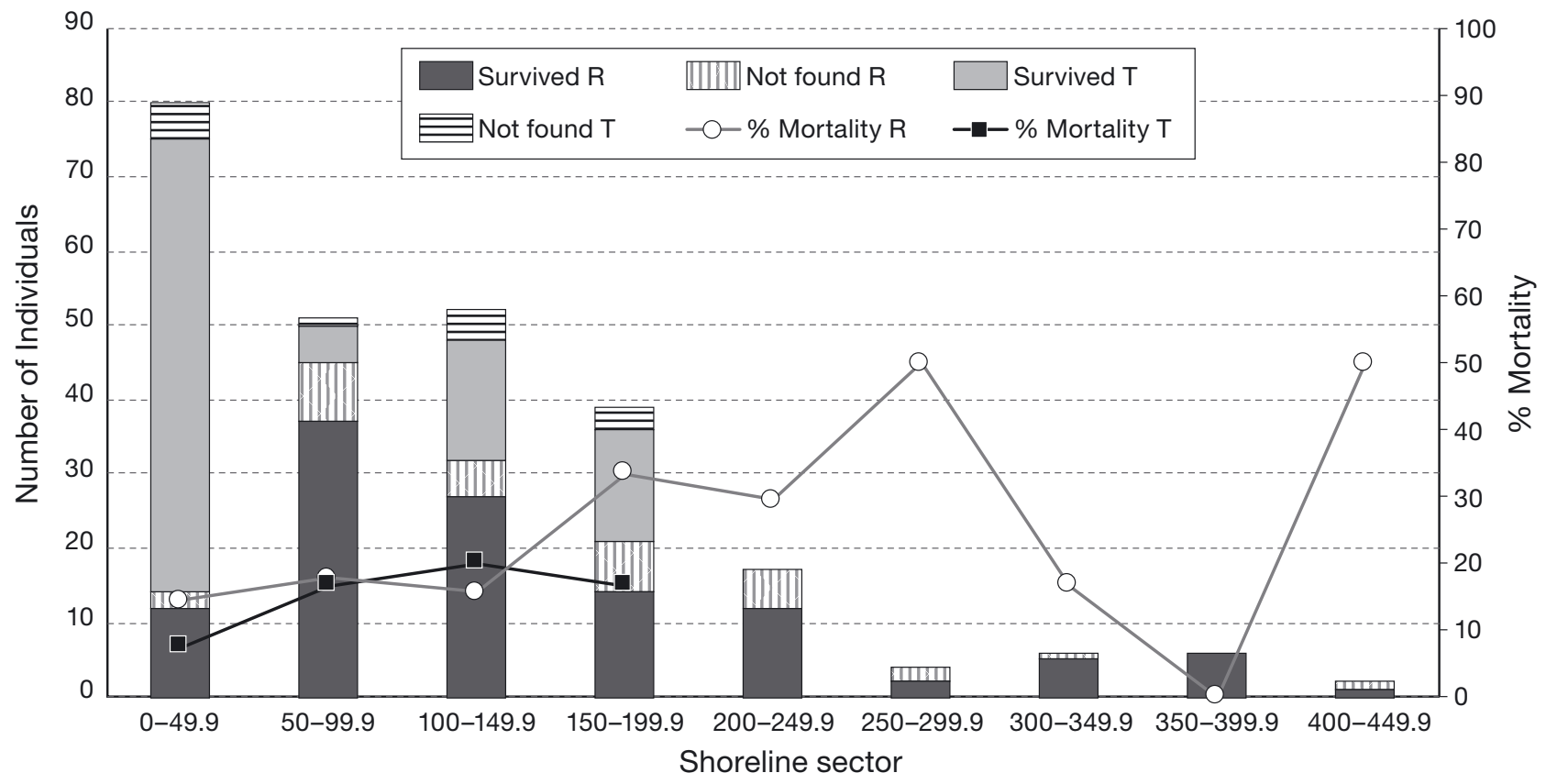

Fig. 8. Numbers of translocated (T) and resident (R) individual Patella ferruginea surviving and lost by the end of the experiment within each $50 \mathrm{~m}$ section of the North Mole surveyed. Line graphs indicate \% mortality for each section 

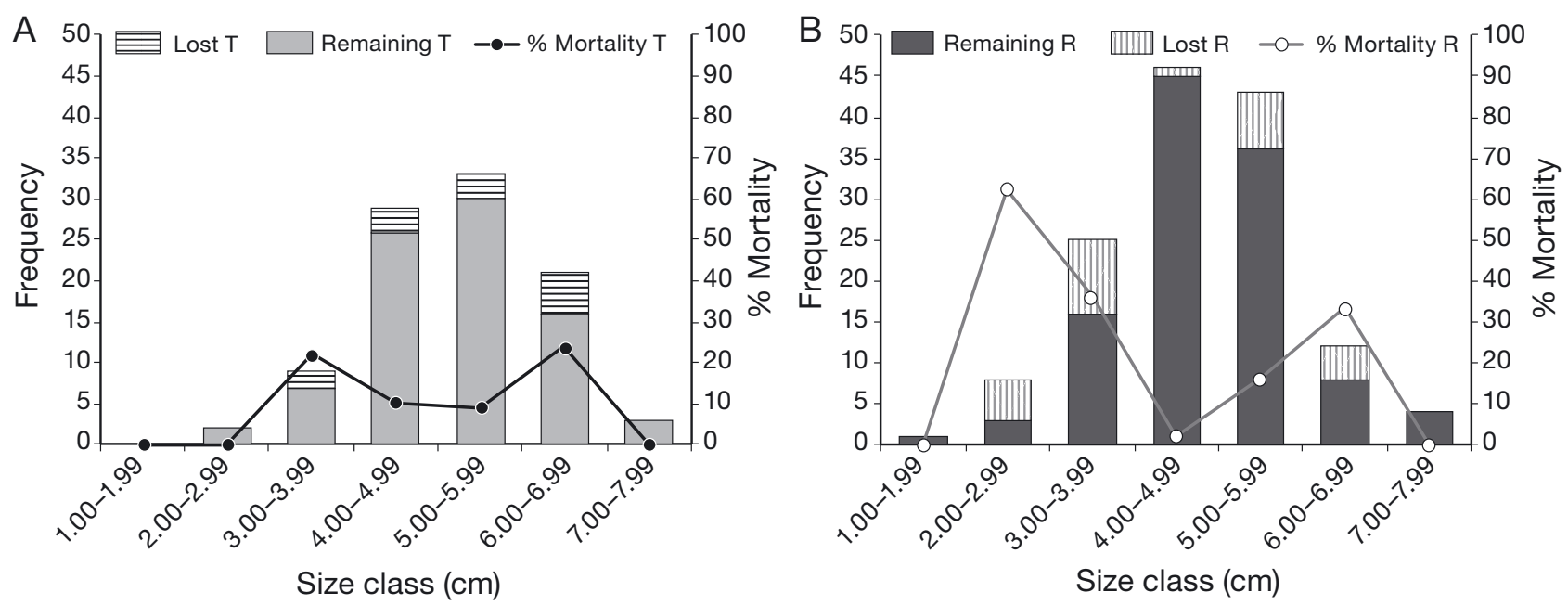

Fig. 9. Numbers of translocated individual Patella ferruginea that survived versus those not found in each size class. The line indicates \% mortality in each size class. (A) Translocated (T) individuals; (B) resident (R) individuals

\section{CONCLUSIONS AND CONSERVATION CONSIDERATIONS}

The continuous presence of relatively small-sized individuals ( 2 to $3 \mathrm{~cm}$ ) reported (Fa 2005, Fa \& Finlayson 2008, present study) establishes that the Gibraltar population is a breeding one, albeit with low observed levels of cohort recruitment. It does, however, invalidate the proposal stated within the MMAMRM (2008) report that this population is probably non-reproducing.

The results obtained here point to an extremely high survivability of the translocated specimens. After $10 \mathrm{mo}$, only $13.4 \%$ of translocated individuals had perished, which compares positively with $21 \%$ mortality of the existing population. The relatively high mortality is probably due to elevated degrees of public access, where the animals are exposed to collection as bait (individual 81 was actually found in a small accumulation of discarded shells from fishing activities), as well as trampling and other physical effects. Further monitoring work is needed to establish the constancy of these effects and the long-term survival of the population, but these initial results are extremely encouraging with regard to the use of the methods described to assist in the conservation of Patella ferruginea as well as other patellids and similar species.

Nevertheless, we cannot stress enough that this should only be considered as an option when there is no other way of conserving $P$. ferruginea individuals in situ. This method should not be regarded as an 'opt-out' in order to avoid threats which could be otherwise directly mitigated without disturbing resident populations. In addition, results may be highly variable in each case, since they depend on multiple factors (i.e. size of the blocks, logistic availabilities, skill of the operators, location of the enclaves of origin and destination).

Taking into account the findings of the present study, for the known remaining existing populations of $P$. ferruginea, a number of measures should be given high priority:

(1) It is most important to carefully protect the largest individuals, since they suffer most from human disturbance, and their removal results in a disproportionate effect on sex ratios and reproductive success (see Guerra-García et al. 2004b). This translocation technique has been shown to not adversely impact individuals of large size, and therefore should be the method of choice for the establishment of actively reproducing 'founder colonies'.

(2) In both fishes and invertebrates, the reserve effect has been shown to favour an increase in the mean size of the specimens (e.g. Edgar \& Barrett 1997). To this end, reserve areas could be created for this species, to act as foci for larval export. Similar areas in Ceuta harbour have been fenced off and have even been fitted with a video surveillance system to protect this species from human disturbance (García-Gómez et al. 2011, 2015, Firth et al. 2016, Shabtay et al. 2018). We recommend the adoption of similar strategies to protect local populations that are in close proximity to potential human impacts. Given the relative success of populations within areas with highly restricted access, such as along the Gibraltar 
Airport runway breakwaters (Espinosa et al. 2008b), we suggest that controlling public access to a few, highly valuable areas will at least help to maintain breeding 'source' populations that can continue to disperse into 'sink' areas (where survivorship may be reduced).

(3) Given the reduced dispersal capabilities of this species, artificial coastal constructions may presently exist which may provide adequate conditions for survival and reproduction. Espinosa \& Ozawa (2006) demonstrated high genetic similarities between the various populations in the area of the Straits of Gibraltar, and therefore this method may also provide a means to 'seed' new locations with individuals sampled from sufficiently large populations, which over time would provide new cohorts to colonise surrounding coastlines, both natural and artificial. Seeded populations may also eventually qualify for designation as AMMRs.

(4) Our results also highlight the possibility of reintroducing adult $P$. ferruginea individuals from artificial coastal works directly into natural habitats. In our case, the survival rate after 10 mo (86.6\%) was higher than that recorded by the method of detaching individuals from substrata, which resulted in around $60 \%$ survival after 10 mo in Zembra (Zarrouk et al. 2018).

Acknowledgements. The authors thank Free Espinosa Torre for access to unpublished data of prior translocation attempts and advice during final editing, and Hannah $\mathrm{Fa}$, Jade Finlayson and Alex Mirza for assistance with fieldwork. This research was partly funded by the Gibraltar Museum, and the Ministry for the Environment, HM Government of Gibraltar. The authors confirm that they have no conflicts of interest to declare.

\section{LITERATURE CITED}

Angel A, Branch GM, Wanless RM, Siebert T (2006) Causes of rarity and range restriction of an endangered, endemic limpet, Siphonaria compressa. J Exp Mar Biol Ecol 330: 245-260

Arroyo MC, Moreno D, Barrajón A, De la Linde A and others (2011) Trabajos de seguimiento de la lapa ferruginosa Patella ferruginea Gmelin, 1791 en Andalucía en el marco de la Estrategia Nacional de Conservación de la especie Mediterránea. Serie de estudios biológicos, Época II, Número especial. Universidad de Alicante, Alicante

Aversano FR (1986) Esperimento di insediamento artificiale di Patella ferruginea Gmelin, 1791 nelle acque del Golfo di Arzachena (Sardegna settentrionale). Boll Malacol 22: 169-170

Bianchi CN, Morri C (2000) Marine biodiversity of the Mediterranean Sea: situation, problems and prospects for future research. Mar Pollut Bull 40:367-376

Borges CD, Hawkins SJ, Crowe TP, Doncaster CP (2016)
The influence of simulated exploitation on Patella vulgata populations: protandric sex change is size dependent. Ecol Evol 6:514-531

Bosman AL, Hockey PAR, Siegfried WR (1987) The influence of coastal upwelling on the functional structure of rocky intertidal communities. Oecologia 72:226-232

Branch GM (1981) The biology of limpets: physical factors, energy flow and ecological interactions. Oceanogr Mar Biol Annu Rev 19:235-380

Bullock JM, Hodder KH, Manchester SJ, Stevenson MJ (1996) Review of information, policy and legislation on species translocation. JNCC Rep No. 261. Joint Nature Conservation Committee, Peterborough

Casu M, Casu D, Lai T, Cossu P, Curini-Galletti M (2006) Inter-simple sequence repeat markers reveal strong genetic differentiation among populations of the endangered mollusc Patella ferruginea (Gastropoda: Patellidae) from two Sardinian marine protected areas. Mar Biol 149:1163-1174

Casu M, Rivera-Ingraham GA, Cossu P, Lai T and others (2011) Patterns of spatial genetic structuring in the endangered limpet Patella ferruginea: implications for the conservation of a Mediterranean endemic. Genetica 139:1293-1308

Cebrian E, Uriz MJ, Garrabou J, Ballesteros E (2011) Sponge mass mortalities in a warming Mediterranean Sea: Are cyanobacteria-harboring species worse off? PLOS ONE 6:e20211

Cossu P, Scarpa F, Dedola GL, Sanna D and others (2017) Surviving at the edge of a fragmented range: patterns of genetic diversity in isolated populations of the endangered giant Mediterranean limpet (Patella ferruginea). Mar Biol 164:41

Cretella M, Scillitani G, Toscano F, Turella P, Picariello O, Cataudo A (1994) Relationships between Patella ferruginea Gmelin, 1791 and the other Tyrrhenian species of Patella (Gastropoda: Patellidae). J Molluscan Stud 60: 9-17

*Di Camillo CG, Cerrano C (2015) Mass mortality events in the NW Adriatic Sea: phase shift from slow-to fast-growing organisms. PLOS ONE 10:e0126689

EC (European Commission) (2004) Council Directive 92/43/ EEC of 21 May 1992 on the conservation of natural habitats and of wild fauna and flora. Off J Eur Comm L 206: 7-50. http://data.europa.eu/eli/dir/1992/43/oj

Edgar GJ, Barrett NS (1997) Short term monitoring of biotic change in Tasmanian marine reserves. J Exp Mar Biol Ecol 213:261-279

Espinosa F (2005) Caracterización biológica del molusco protegido Patella ferruginea Gmelin, 1791 (Gastropoda: Patellidae): bases para su gestión y conservación. $\mathrm{PhD}$ thesis, University of Seville

Espinosa F, Ozawa T (2006) Population genetics of the endangered limpet Patella ferruginea (Gastropoda: Patellidae): taxonomic, conservation and evolutionary considerations. J Zoological Syst Evol Res 44:8-16

Espinosa F, Rivera-Ingraham GA (2017) Biological conservation of giant limpets: the implications of large size. Adv Mar Biol 76:105-155

Espinosa F, Fa DA, Ocaña TMJ (2005) Estado de la especie amenazada Patella ferruginea Gmelin, 1791 (Gastropoda: Patellidae) en la bahía de Algeciras y Gibraltar. Iberus 23:39-46

*Espinosa F, Guerra-García J, Fa D, García-Gómez JC (2006) Aspects of reproduction and their implications for the 
conservation of the endangered limpet, Patella ferruginea. Invertebr Reprod Dev 49:85-92

Espinosa F, González-Aranda AR, Maestre-Delgado MJ, Fa D, Guerra-García JM, García-Gómez JC (2007) Preliminary observations on activity rhythms and foraging behaviour in the endangered limpet Patella ferruginea: influence of environmental factors. Dong Wu Xue Bao 53:179-183

Espinosa F, Rivera-Ingraham R, García-Gómez JC (2008a) Seasonal activity and foraging behaviour of the endangered limpet Patella ferruginea. Ethol Ecol Evol 20:173-181

* Espinosa F, González AR, Maestre MJ, Fa D, Guerra-García JM, García-Gómez JC (2008b) Responses of the endangered limpet Patella ferruginea to reintroduction under different environmental conditions: survival, growth rates and life-history. Ital J Zool 75:371-384

Espinosa F, Rivera-Ingraham GA, Maestre M, González AR, Bazairi H, García-Gómez JC (2014) Updated global distribution of the threatened marine limpet Patella ferruginea (Gastropoda: Patellidae): an example of biodiversity loss in the Mediterranean. Oryx 48:266-275

Fa DA (2005) Report on survey of the North Mole and surrounding coastlines to investigate the presence of Patella ferruginea Gmelin, 1791, a protected species in danger of extinction. Produced for the Ministry for Trade, Industry and Communications, HM Government of Gibraltar. Available from the Ministry of the Environment and Climate Change, HM Government of Gibraltar

Fa DA (2008) Effects of tidal amplitude on intertidal resource availability and dispersal pressure in prehistoric human coastal populations: the Mediterranean-Atlantic transition. Quat Sci Rev 27:2194-2209

Fa DA, Finlayson G (2008) Marine surveillance — diving and intertidal survey. Report outlining the distribution and conservation status of four EU-protected marine species (Patella ferruginea, Pinna nobilis, Lithophaga lithophaga and Centrostephanus longispinus). Produced for the Ministry of the Environment and Climate Change, HM Government of Gibraltar

Fauvelot C, Bertozzi F, Costantini F, Airoldi L, Abbiati M (2009) Lower genetic diversity in the limpet Patella caerulea on urban coastal structures compared to natural rocky habitats. Mar Biol 156:2313-2323

Fernández CM, Arroyo MC, Soledad VM (2017) Caracterización de las poblaciones de la lapa ferruginosa (Patella ferruginea Gmelin, 1971) de la costa norte del estrecho de Gibraltar. Almoraima. Instituto de Estudios Campogibraltareños 47:181-202

Firth LB, Knights AM, Bridger D, Evans AJ and others (2016) Ocean sprawl: challenges and opportunities for biodiversity management in a changing world. Oceanogr Mar Biol Annu Rev 54:193-269

Frenkiel L (1975) Contribution à l'étude des cycles de reproduction des Patellidae en Algérie. Pubbl Stn Zool Napoli 39:153-189

*García-Gómez JC, López-Fé CM, Espinosa F, GuerraGarcía JM, Rivera-Ingraham GA (2011) Marine artificial micro-reserves: a possibility for the conservation of endangered species living on artificial substrata. Mar Ecol 32:6-14

* García-Gómez JC, Guerra-García JM, Espinosa F, Maestre MJ and others (2015) Artificial marine micro-reserves networks (AMMRNs): an innovative approach to conserve marine littoral biodiversity and protect endangered species. Mar Ecol 36:259-277
González JA, Paredes P, Enrique C, Calzado P, Bueno I (2015) Patella ferruginea, patrimonio del litoral melillense: biología, ecología y conservación. GEEPP Ediciones, Melilla

Griffith B, Scott JM, Carpenter JW, Reed C (1989) Translocation as a species conservation tool: status and strategy. Science 245:477-480

Guallart J (2006) Estado de Patella ferruginea en las Islas Chafarinas y estudios previos para la traslocación de ejemplares: informe final. OAPN, Ministerio de Agricultura, Pesca y Alimentación, Madrid. https://www. mapama.gob.es/es/parques-nacionales-oapn/centrosfincas/chafarinas/2006-patella-ferruginea-chafarinasguallart_tcm30-288639.pdf

Guallart J (2014) Condicionantes de la biología de la lapa ferruginosa (Patella ferruginea) en vistas a potenciales traslados de ejemplares. Informe técnico, Ministerio de Agricultura, Alimentación y Medio Ambiente, Madrid

Guallart J, Acevedo I (2006) Observaciones sobre la biología de la lapa Patella ferruginea (Mollusca, Patellidae) en las islas Chafarinas. Book of Abstracts, XIV Simposio Ibérico de Estudios de Biología Marina, Barcelona, p 140-141

Guallart J, Calvo M, Acevedo I, Templado J (2013) Two-way sex change in the endangered limpet Patella ferruginea (Mollusca, Gastropoda). Invertebr Reprod Dev 57: 247-253

*Guerra-García JM, Corzo J, Espinosa F, Fa D, GarcíaGómez JC (2004a) Extinction risks and harbours as marine reserves? J Molluscan Stud 70:96-98

* Guerra-García JM, Corzo J, Espinosa F, García-Gómez JC (2004b) Assessing habitat use of the endangered marine mollusc Patella ferruginea (Gastropoda, Patellidae) in northern Africa: preliminary results and implications for conservation. Biol Conserv 116:319-326

*Hoegh-Guldberg O, Hughes L, McIntyre S, Lindenmayer DB, Parmesan C, Possingham HP, Thomas CD (2008) Assisted colonization and rapid climate change. Science 321:345-346

IUCN/SSC (2013) Guidelines for reintroductions and other conservation translocations, version 1.0. IUCN Species Survival Commission, Gland

Laborel-Deguen F, Laborel J (1990) Nouvelles données sur la patelle géante Patella ferruginea Gmelin en Méditerranée. II. Ecologie, biologie, reproduction. Haliotis 10: $55-62$

Laborel-Deguen F, Laborel J (1991a) Statut de Patella ferruginea Gmelin en Méditerranée. In: Boudouresque $\mathrm{CF}$, Avon M, Gravez V (eds) Les espèces marines à protéger en Méditerranée. GIS Posidonie Publishers, Marseille

Laborel-Deguen F, Laborel J (1991b) Nouvelles observations sur le population de Patella ferruginea Gmelin de corse. In: Boudouresque CF, Avon M, Gravez V (eds) Les espèces marines à protéger en Méditerranée. GIS Posidonie Publishers, Marseille

Le Quesne WJ (2005) The response of a protandrous species to exploitation, and the implications for management: a case study with patellid limpets. PhD thesis, University of Southampton

* Maldonado M, Sánchez-Tocino L, Navarro C (2010) Recurrent disease outbreaks in corneous demosponges of the genus Ircinia: epidemic incidence and defense mechanisms. Mar Biol 157:1577-1590

Mau A, Jha R (2017) Aquaculture of two commercially important molluscs (abalone and limpet): existing knowledge and future prospects. Rev Aquacult 10:611-625 
MMAMRM (Ministerio de Medio Ambiente, Medio Rural y Marino) (2008) Estrategia para la conservación de la lapa ferruginea (Patella ferruginea) en España. Conferencia Sectorial de Medio Ambiente, Ministerio de Medio Ambiente, Medio Rural y Marino, Madrid

Müller H, Eriksson O (2013) A pragmatic and utilitarian view of species translocation as a tool in conservation biology. Biodivers Conserv 22:1837-1841

Pairaud IL, Bensoussan N, Garreau P, Faure V, Garrabou J (2014) Impacts of climate change on coastal benthic ecosystems: assessing the current risk of mortality outbreaks associated with thermal stress in NW Mediterranean coastal areas. Ocean Dyn 64:103-115

Peña JB, Guallart J, Pérez J (2012) Comportamiento de los juveniles de la lapa amenazada Patella ferruginea Gmelin, 1791 (Mollusca, Patellidae) en tanques de cultivo. Rev Investig Mar 19:121-123

Ramos MA (1998) Implementing the Habitats Directive for mollusc species in Spain. J Conchol Spec Publ 2:125-132

Rivera-Ingraham GA (2010) Biología de la conservación de especies de patélidos en el umbral Atlántico-Mediterráneo. $\mathrm{PhD}$ thesis, University of Seville

Rivera-Ingraham GA, Espinosa F, García-Gómez JC (2011a) Conservation status and updated census of Patella ferruginea (Gastropoda, Patellidae) in Ceuta: distribution patterns and new evidence of the effects of environmental parameters on population structure. Anim Biodivers Conserv 34:83-99

Rivera-Ingraham GA, Espinosa F, García-Gómez JC (2011b) Environmentally mediated sex change in the endangered limpet Patella ferruginea (Gastropoda: Patellidae). J Molluscan Stud 77:226-231

Editorial responsibility: David Richardson, Norwich, UK
Rivera-Ingraham GA, Espinosa F, García-Gómez JC (2015) Long-term monitoring of the critically endangered limpet Patella ferruginea Gmelin, 1791: new ecological insights and first demographic results. J Molluscan Stud 81:124-130

* Rivetti I, Fraschetti S, Lionello P, Zambianchi E, Boero F (2014) Global warming and mass mortalities of benthic invertebrates in the Mediterranean Sea. PLOS ONE 9: e115655

Rivetti I, Boero F, Fraschetti S, Zambianchi E, Lionello $P$ (2017) Anomalies of the upper water column in the Mediterranean Sea. Global Planet Change 151: 68-79

Shabtay A, Portman ME, Carmel Y (2018) Contributions of marine infrastructures to marine planning and protected area networking. Aquat Conserv 28:830-839

* Sherrard TR, Hawkins SJ, Barfield P, Kitou M, Bray S, Osborne PE (2016) Hidden biodiversity in cryptic habitats provided by porous coastal defence structures. Coast Eng 118:12-20

*Swan KD, McPherson JM, Seddon PJ, Moehrenschlager A (2016) Managing marine biodiversity: the rising diversity and prevalence of marine conservation translocations. Conserv Lett 9:239-251

Wright WG (1989) Intraspecific density mediates sex-change in the territorial patellacean limpet Lottia gigantea. Mar Biol 100:353-364

Zarrouk A, Romdhane MS, Espinosa F (2018) Reintroduction of the highly endangered mollusk Patella ferruginea Gmelin, 1791 in an MPA: a novel approach to achieve high survival rates. Estuar Coast Shelf Sci 202:259-269

Submitted: April 10, 2018; Accepted: August 8, 2018 Proofs received from author(s): September 24, 2018 